\title{
Regulated Fishery Is Beneficial for the Sustainability of Fish Population in Lake Kinneret (Israel)
}

\author{
Moshe Gophen', Oren Sonin², Menachem Lev³, Gregory Snovsky² \\ ${ }^{1}$ Migal-Scientific Research Institute, Kiryat Shmone, Israel \\ ${ }^{2}$ The Fisheries Department, Israeli Ministry of Agriculture and Rural Development, Tiberias, Israel \\ ${ }^{3}$ Kibutz Ein-Gev, Fishery Branch, MP Jordan Valley, Israel \\ Email: Gophen@Migal.org.il, Orens@moag.gov.il, Gregorys@moag.gov.il, Mlev04@gmail.com
}

Received 15 September 2015; accepted 23 October 2015; published 26 October 2015

Copyright (C) 2015 by authors and Scientific Research Publishing Inc.

This work is licensed under the Creative Commons Attribution International License (CC BY). http://creativecommons.org/licenses/by/4.0/

(c) $\underset{\mathrm{EY}}{\mathrm{B}}$ Open Access

\begin{abstract}
Analysis of long-term data-sets of limnological and ichthyological features of the Lake Kinneret ecosystem structure revealed evidence that the decline of fish landings during 2007-2008 was not an unpredicted crisis and included only Tilapias, and mostly S. galilaeus. Several factors were found to be responsible for the decline and recovery afterwards: decline of stocking, enhancement of population size of food competitors (Bleaks), the use of smaller mesh size of fishing nets, increase of predation pressure by Cormorants, the burst of Viral Disease, natural cyclic oscillation of ENSO event and its higher frequencies and intensities during the 2000's. Therefore, recommendations aimed at ceased fishing are not justified and fishery continuation is correct: renewal of Bleaks fishing effort, improvement of fishing legislations, enforcement and management of fish stocking, and efficient implementation of Cormorants deportation.
\end{abstract}

\section{Keywords}

Sarotherodon galilaeus, Bleaks, Fishery Crisis, Cormorants, Viral Disease, Environmental Conditions

\section{Introduction}

During the last 20 years the Kinneret ecosystem structure has undergone significant modifications. The major change was a turnaround of nutrient availabilities from Phosphorus to Nitrogen limitation within the trophic pyramide structure. The algal dominance of the bloom forming Pyrrhophyte Peridinium was replaced by Cyano- 
bacteria, mostly Microcystis [1] and fish food resources were modified respectively. Independently, other external natural and anthropogenic constrains created an additional pressures on the fishery: population increase of the migratory fish predator, Great Cormorant (Phalacrocorax carbo) in the lake, reduction of stocked fingerlings of Tilapia, the use of small mesh-size fishing nets, the elimination of Bleaks fishing, and outburst of virus disease which infected mostly Tilapias.

A fishery crisis alert was raised when landings of S. galilaeus in 2007-2008 declined to less than 10 tons in 2008 whilst previously it was much higher. An ad-hoc emergent meeting was assembled and a resolution was suggested to recommend a total three-year complete closure on fishing activity in Lake Kinneret. A group of scientists strongly opposed this resolution and alternately recommended to continue fishing under legal legislations as normally implemented earlier. The fishing continuation was accepted by governmental authorities. Five years after the crisis of $S$. galilaeus fishing, their population recovered and landings were renewed up to the normal earlier level. In this paper we analyze the case of this crisis and recovery. The rational of the objection to fishery stop and its implementation, and the outcome of the S. galilaeus population recovery are presented.

During 2007-2008, landings of S. galilaeus sharply declined from earlier 200 - 400 tons annually to less than 10 tons in 2008. We indicated several factors as the reasons for this decline: 1) reduction of S. galilaeus stocking; 2) the illegal use of small mesh-size fishing nets; 3 ) ecological changes of the disappearance of the bloom forming dinoflagellate Peridinium and its replacement by Cyanobacteria; 4) proliferation of the Bleaks (Cyprinidae, Mirogrex terraesanctae terraesanctae, Acanthbrama lissneri Lavnun, Kinneret Bleak) that resulted in competition between Bleaks and S. galilaeus for their zooplankton food resources; 5) an outburst of viral disease that infected Tilapias, mostly S. galilaeus and Tristramella simonies simonis (TilV-RNA-NODA-the blindness disease); 6) intensification of Cormorant predation accompanied by the normal catfish piscivory of fingerlings and sub-commercial size of S. galilaeus; 7) natural cyclic fluctuations of S. galilaeus stock; 8) fishermen activities and fish behavior under pressure: the heavier fishing pressure on S. galilaeus that was initiated by fishermen and Cormorant caused an essential migration of this fish to find a refuge in deeper depths, making its detection and fishing more difficult.

These factors and the shifting of the fishery efforts to Tilapias, whilst Bleaks fishing was independently targeted on market demand, made the overall regulation a complicated objective. The fishery design in Lake Kinneret is aimed at both fishermen income and water quality protection, and will be presented and discussed in this paper.

\section{Methods}

The limnological long term (1970-2013) data-set (nutrient, phytoplankton, fish densities as monitored by echosurveys) and the Blindness disease were taken from [2]. The fishery landings by species and information on fishery legislations as well as the early reports on Blindness disease were taken from the annual reports [3].

\section{Cormorant Studies}

A research of the potential impact of Cormorant was carried out by the National Authority of Nature and Parks Authority (NPA) and preliminary results were published as interim reports. The food consumption by Cormorants was documented in NPA's reports. NPA together with the Fishery Department of the Ministry of Agriculture were responsible for the assessment of population size of Cormorant. The number and identification of daily preyed fishes by Cormorants were studied by NPA by daily collection of regurgitated pellets in one of the several Cormorant overnight-staying sites.

\section{Results and Discussion}

\subsection{Limnological Changes in the Kinneret Ecosystem}

Since mid 1990s the Kinneret ecosystem has undergone limnological structure modifications [1]-[7]. The crucial change was the decline of Nitrogen accompanied by a slight increase of Phosphorus concentrations in the epilimnion. Ensuing lowering of the epilimnetic TN/TP mass ratio was resulted in. The newly developed nutrients ratio created a change of the trophic status from $\mathrm{P}$ to $\mathrm{N}$ limitation. Under $\mathrm{N}$ limitation the contribution of recycled P by zooplankton might enhance phytoplankton growth [4] [7] [8]. The practical implication of that is a threat on water quality, resulted by Cyanobacteria blooms increase. The decline of $\mathrm{N}$ was recorded in the epi- 
limnion of Lake Kinneret as early as mid 1980s. Before mid 1980’s the availability of N was sufficient, and P was limited. A slight Increase of $\mathrm{P}$ together with $\mathrm{N}$ decline created $\mathrm{N}$ limitation for Peridinium growth but it is optimal for Cyanobacteria [1] [4] [8] and also for diatoms and chlorophytes. As a consequence Peridinium declined and other algae (Cyanophyta, Bacillariophyta, Chlorophyta) were enhanced. The decline of water level which caused a decrease of the thermocline depth, is attributed to the higher frequency of droughts, which reduced input of both water and nutrients (mainly Nitrogen). In addition, sewage effluents were treated and reused. The result was divertion of Nitrogen from the lake. Moreover, the frequency of dust storms in the Hula Valley was reduced and fishponds area was restricted from 1700 to 350 ha. All these anthropogenic activities caused a reduction of external N flux into Lake Kinneret. Due to the N limitation, and the Peridinium decline [1] [4] [8], the nano-phytoplankton, dominated by Cyanobacteria, especially Microcystis spp. occupied the free (no Peridinium) niche. These changes initiated modifications of food resources and feeding habits of fish. Peridinium gatunenze was the major food component of the most valued native fish, Sarotherodon galilaeus, in the lake [1] [5]-[7]. It is likely that in the present conditions the impact of recycled P by zooplankton may not be negligible [8]. Zooplankton is the major food constituent of the food of the endemic Cyprinid, Bleaks [5]-[7]. For the improvement of water quality in Lake Kinneret the maintenance of high grazing pressure by zooplankton on nano-phytoplnkton is advisable. Therefore, partial removal of (unwanted) bleaks by fishery management and introduction of the exotic Silver Carp (Hyphophthalmichthis molitrix), an efficient consumer of Microcystis, will be beneficial. A cardinal question is therefore raised: If intensification of zooplankton predation is not advisable and Bleaks are not commercially deserved, and if the market demands of S. galilaeus, which is presently consume zooplankton, are the highest, who is more appropriate component as consumer of zooplankton? Bleaks or S. galilaeus.

If fishing would be ceased-proliferated bleaks would be resulted and suppression of S. galilaeus is therefore predicted.

When algal photosynthetic activity is carried out under $\mathrm{N}$ limitation their nutrition value is lower, and therefore limits zooplankton growth [9]. Zooplankton is also important in lakes because their excretions contributes inorganic $\mathrm{N}$ and $\mathrm{P}$ for phytoplankton and bacterial production. Urabe [10] demonstrated regeneration of $\mathrm{N}$ and $\mathrm{P}$ by zooplankton and their subsequent utilization by phytoplankton. Zooplankton biomass in Lake Kinneret declined from 1970 until early 1990s but increased afterwards. Both, biomass and size frequency of cladocerans were affected by fish predation [5]. It is likely that elevation of zooplankton biomass contributes to suppression of nano-phytoplankton biomass whilst $\mathrm{P}$ regenerated by zooplankton will improve their growth. There are two contradicted processes: fish (mostly Bleaks) zooplanktivory effect which reduce pressure from nano-phytoplankton and $\mathrm{P}$ regeneration by zooplankton which enhance algal growth. The control of nano-phytoplankton is aimed at ensuring water quality and can be achieved by Bleaks removal. The recovery of $S$. galilaeus population together with renewal of Bleak fishing will probably release zooplankton sources to S. galilaeus and enhance reduction of zooplankton predation pressure. The combined manipulation of recovered S. galilaeus, and low Bleaks biomass (by fishing) is an advantage for zooplankton increase. High zooplankton is optimal for S. galilaeus recovery, fishermen income and ensure water quality. The implications for lake management are as follows.

The changes of the phytoplankton community structure affected both water quality and the pattern of energy flow through the food web channels. Presently, the major stock of carbon, that was stocked within the Peridinium bloom was replaced by nano-phytoplanktonic components, mainly Cyanobacteria. Because of these changes, zooplankton became major food resource for S. galilaeus which potentially competing with Bleaks. Cyanobacteria species included toxins (Microcystins) causing concern about safety of water supply. The achievement of fish population reclamation is therefore, primarily aimed at S. galilaeus enhancement and could be accomplished by, among others, reduction of Bleaks pressure from zooplankton.

\subsection{Fishery Changes}

During the N limited period, since mid 1990's, considerable changes in the fishery were recorded in Lake Kinneret (Figures 1-7). Landings of Bleaks, Tilapias (O. aureus, S. galilaeus) and Tristramella sp., significantly declined during the 2000's but were affected by different factors: Tilapias by several factors as described previously and Bleaks by fishing stop (Figure 1, Figure 4). Figure 2 and Figure 5 confirm the linear relation between 

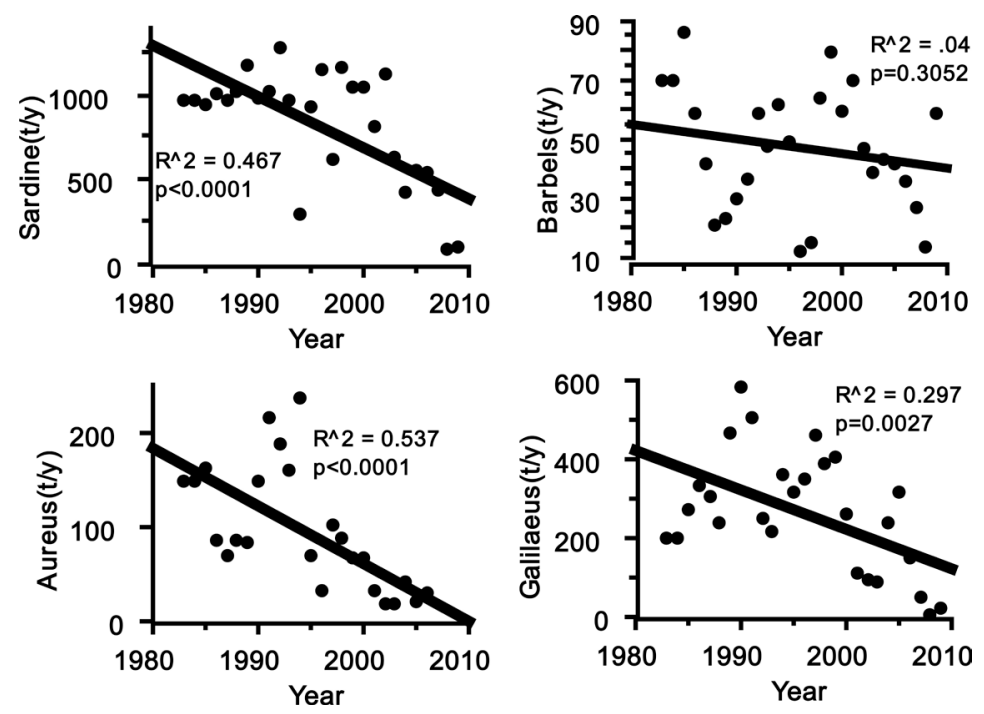

Figure 1. Linear regression ( $\mathrm{r}^{2}$ and $\mathrm{p}$ values are given) between annual (1980-2010) landings ( $\mathrm{t} / \mathrm{y}$ ) of $O$. aureus, bleaks (sardine) vs. years, (left panels); Barbels, and $S$. galilaeus (right panels) vs. years.

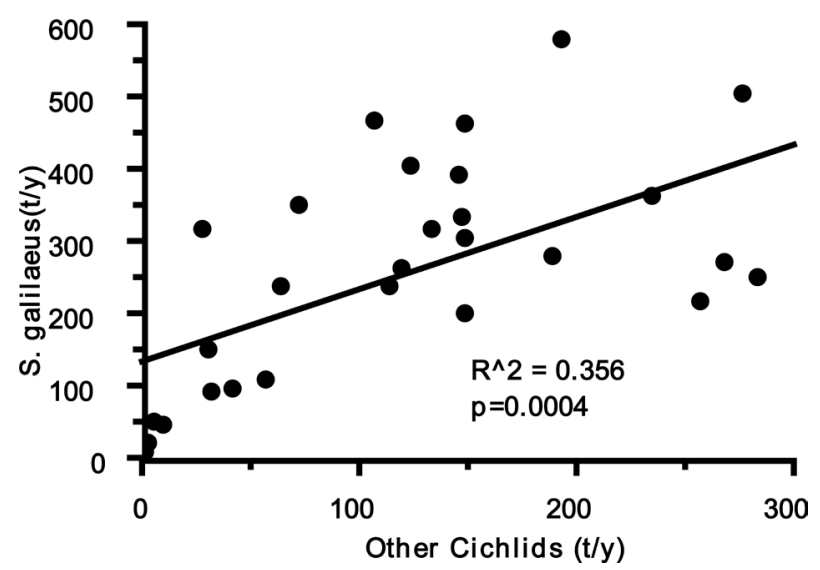

Figure 2. Linear regression ( $\mathrm{r}^{2}$ and $\mathrm{p}$ values are given) between annual (1980-2010) landings (t/y) of S. galilaeus and other cichlids.

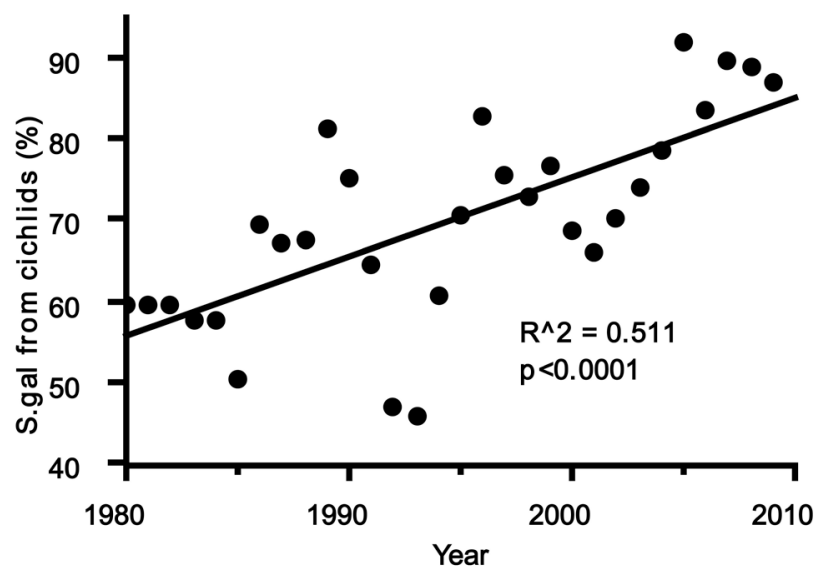

The $\%$ of S.gal. from all Cichlids Catch as averaged for $1980-2015=70 \%$ (SD 12)

Figure 3. Linear regressions ( $\mathrm{r}^{2}$ and $\mathrm{p}$ values are given) between $\%$ of S. galilaeus annual landings from all other cichlids and years (1980-2010). 

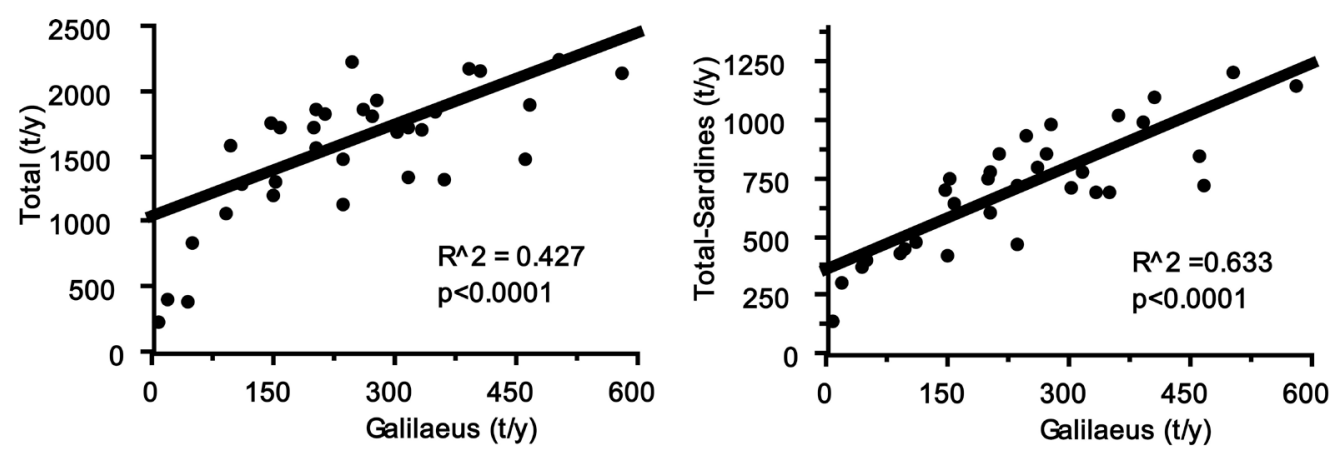

Averaged (SD) \% of Galilaeus from

Av eraged \% (SD) of Galilaeus from Total: 14 (6) t/y

Av eraged \% (SD) of Galilaeus from Total: 55 (12) t/y

Figure 4. Linear regression ( $\mathrm{r}^{2}$ and $\mathrm{p}$ values are given) between total landings (t/y) (left) and total landings minus sardine (bleaks) (right) vs. landings of S. galilaeus (t/y).
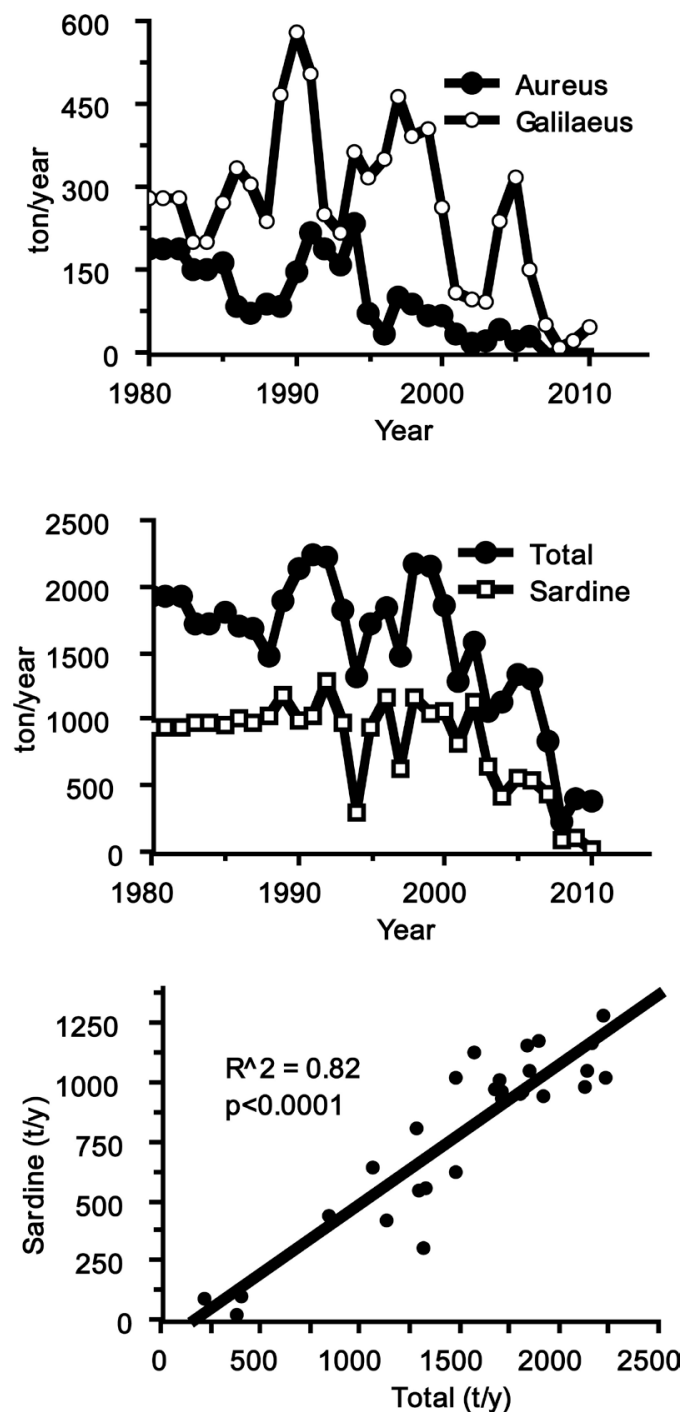

Figure 5. Linear regression ( $\mathrm{r}^{2}$ and $\mathrm{p}$ values are given) between bleaks (sardine) and total (t/y) (lower); annual fluctuations of total and sardine (bleaks) landings (t/y) (middle); annual fluctuations of Tilapias (S. galilaeus, O. aureus) landings (t/y) (upper). 

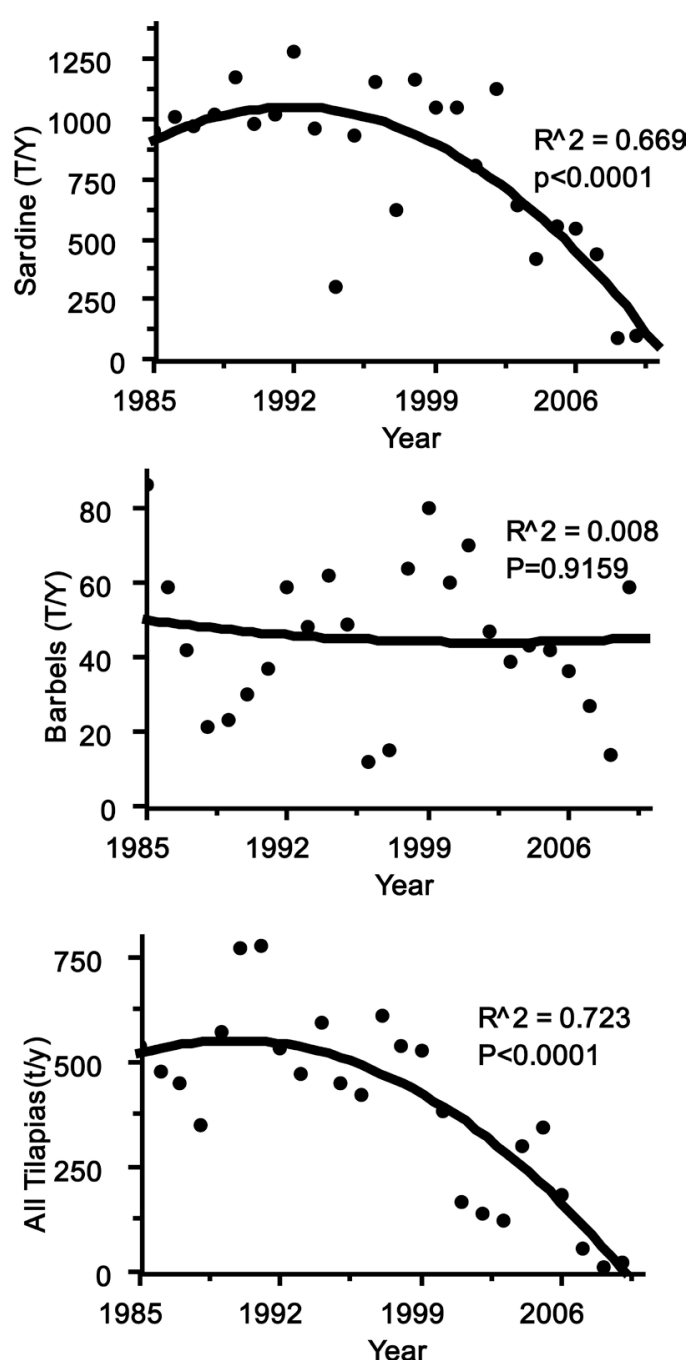

Figure 6. Polynomial regressions $\left(\mathrm{r}^{2}\right.$ and $\mathrm{p}$ values are given) ( $\mathrm{S}=$ significant; NS = not significant) between: 1$)$ upper: (s) bleaks annual landings (t/y) vs. years; 2) middle: (NS) barbels annual landings vs. years; 3) lower: (S) annual landings of all tilapias vs. years.
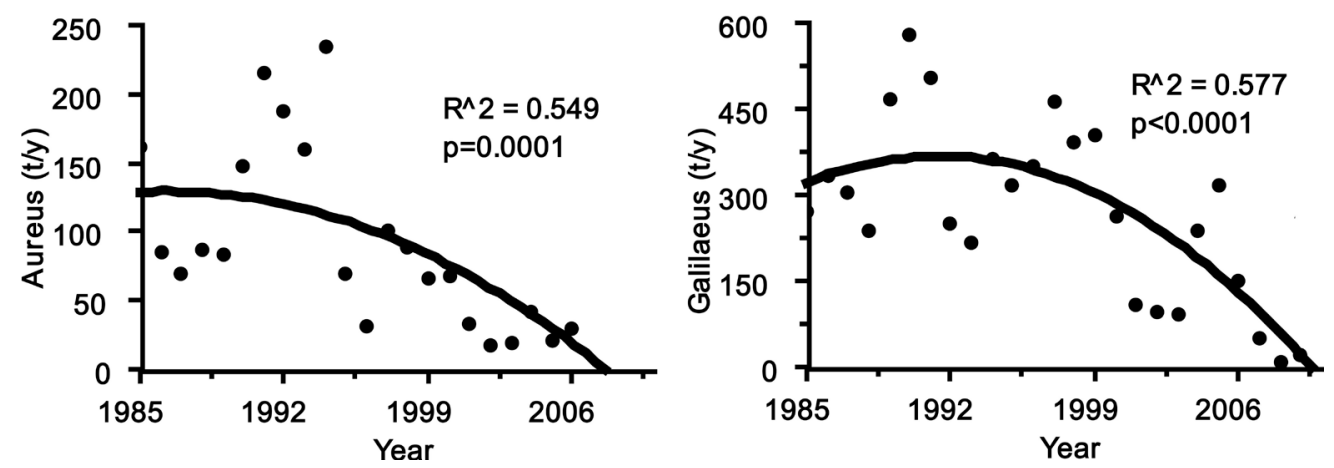

Figure 7. Polynomial regressions ( $\mathrm{r}^{2}$ and p values are given) ( $\mathrm{S}=$ significant; NS = not significant) between: 1$)$ left: (S) $O$. aureus annual landings (t/y) vs. years; 2) right: (S) annual landings of S. galilaeus vs. years.

landings of S. galilaeus and other Tilapias. Therefore, the percentage of S. galilaeus landing from the total Tilapias catch is increasing when total Tilapias decline. Polynomial regressions (Figure 6, Figure 7) confirm the timing relation between landings of Tilapias and Bleaks but insignificant for Barbels. That is probably because 
the affected factors to those discussed in this paper are not relevant to Barbels. The population of S. galilaeus sharply declined, resulting in reductions in fish annual yields from 350 tons during the 1990's to 8 tons in 2008 (Figure 4). $\Delta^{13} \mathrm{C}$ analyses of $S$. galilaeus indicated a slight change of the trophic status of this fish during 20082009: from $-21.7 \%$ to $-24.1 \%$ [2] probably due to the partial shift of the feeding habit of S. galilaeus from $P e-$ ridinium to zooplankton.

S. galilaeus fishery is not limited by market demands but only by its catchability. S. galilaeus is routinely stocked since 1958 but its introduction was reduced from late 1990's (Figure 10). Fingerlings of S. galilaeus, are successfully raised in artificial ponds located in the Ginosar, Aquaculture Research Station, in the vicinity of the lake by experts of the Fishery Department. About 1000 - 1200 adult couples, males and females, of S. galilaeus are collected in the lake and placed in each 1 ha of two pond. The bottom of these ponds is covered by Plastic sheet with concrete bricks scattered on it. These bricks successfully create simulation of spawning ground. The full process of courtship, egg laying, fertilization, mouth breeding and the larval-fingerling growth maintenance is done in the ponds. The fingerlings are raised by feeding with artificial food (pellets). The fishes in the ponds are supplied by optimal maintenance conditions of feeding, aeration and water exchange which continue until fingerlings weight is raised to 5 - $10 \mathrm{~g} / \mathrm{ind}$. Fingerlings are gradually collected and transferred immediately into the lake. Stocking season is from August to October and number of introduced fingerlings is financially limited by nurseries maintenance expenses.

Bleak fishery was totally ceased after 2000 because of market limitations (low commercial value), leading to a dramatic increase of their population in the lake [11]. A prominent increase of fish densities was indicated probably due mostly to bleak shoals (Figure 6). Because Bleaks are not fished as before the 2000's because of the market demands dependence their catch is not representing their population in the lake.

Nevertheless, the $S$. galilaeus landings sharply declined (Figure 8, Figure 9). Illegal small mesh size of the gill net fishery was unfortunately also recorded.

At present there seems to be competition for zooplankton food source between Bleaks and S. galilaeus. If hydrological conditions will be improved and additional supply of external Nitrogen will be enhanced, and the epilimnetic stock of $\mathrm{N}$ will be restored, the Peridinium blooms re-appearance is predicted. Such cases were already sporadically documented during the winter floods in 1992 and 2003. If nutrient availabilities return to the previous conditions, and planktonic food resources as well, the present status of S. galilaeus could probably reversed to previous situation. If Peridinium blooms returns, the presence of S. galilaeus is desireale for suppressing the Peridinium biomass because this fish consume this algae more efficiently than any other fish in the lake [5]-[8]. The ecological contribution of S. galilaeus to the ecosystem flow through the consumption of Peridinium biomass that was common in the past and could easily reappeared. Consequently, the actual advisable management is proposed at optimal fishery with benefits of both water quality protection and fisher (presently approved title for fishermen) income.

The answer given in this paper is an objection to the proposition submitted to the Ministry of Agriculture and water Authority of three years total ceased-fishing (CeFi) in Lake Kinneret. The Israeli government approved the CeFi proposal but a group of scientists and Fisher opposed it and after intensive professional discussions the government withdrew and canceled the fishing stop resolution. The justification of it was evidently approved by the recovery of Tilapias landings later. Essentially, it was predicted that total elimination of fishery, will give an open niche for proliferation of the Bleak population (Figure 6) leading to reduction in zooplankton biomass, and increase in nano-phytoplankton. Therefore, S. galilaeus population would not recover because bleak is a more efficient predator of zooplankton [5] [6].

Conclusively, the CeFi proposal would culminate deterioration of water quality without advantage to Fisher crops. Objections to CeFi proposal were accompanied by constructive proposals like radical removal of Cormorants, enforcement of the use of larger (legal) mesh size for gill nets and others. A new program which replaced the governmental CeFi resolution was accepted including, among others, Cormorant deportation, stocking enhancement of large size (5 - 10 g/ind) fingerlings, renewal of Bleak fishing and usage of larger fishing mesh size.

\subsection{Clarias Predation [12]}

The catfish, Clarias gariepinus (syn. C. lazera) is a native tropical component of the Kinneret Ichthyofauna. This fish has a very low market demands and therefore its contribution to the total annual landings is negligible. The fish comprise $<5 \%$ of total landings. Very high density of catfishes are usually observed during summer- 


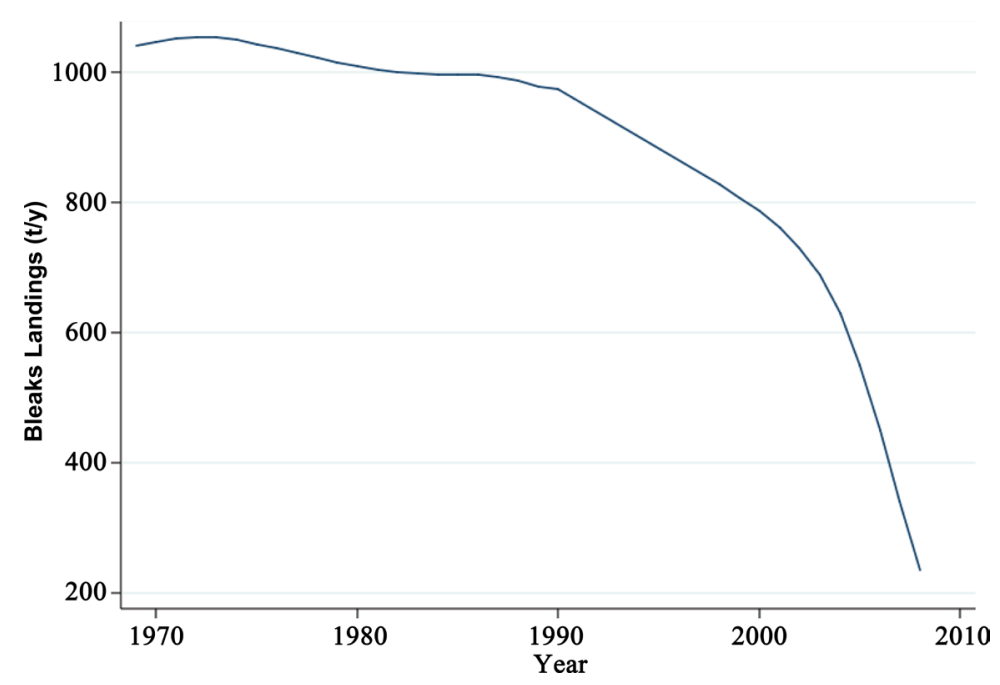

Figure 8. Total catch (t/y) bleaks (1970-2010) LOWESS (0.8).

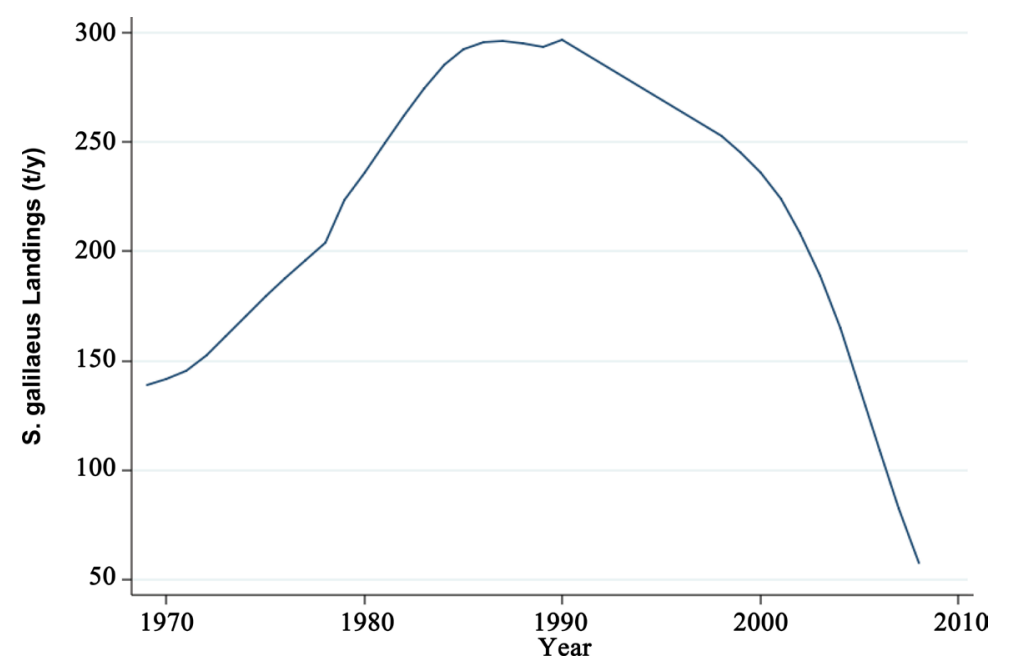

Figure 9. Total catch (t/y) of Sarotherodon galilaeus (1970-2010) LOWESS (0.8).

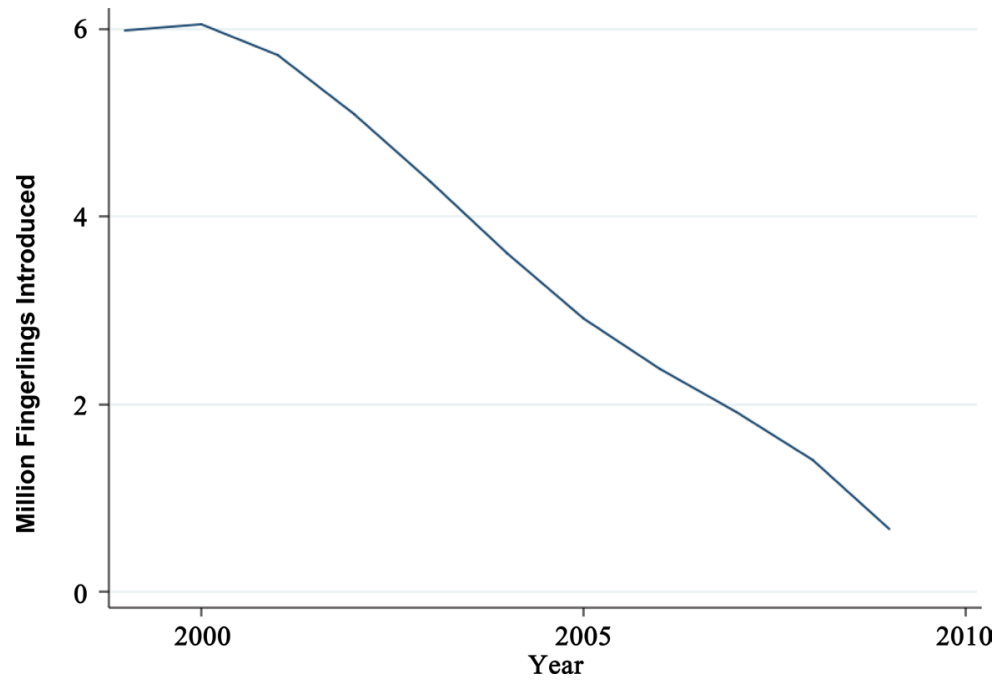

Figure 10. Sarotherodon galilaeus introduction (10\%/y) 1998-2009; LOWESS (0.8). 
fall season close to the introduction site of $S$. galilaeus fingerlings, probably for chasing vulnerable fingerlings prey. The food composition of Catfish was studied [12] during two seasons: 1973-1975 and 1981-1982. The composition of 264 alimentary canal of adult specimen (TL $23.8-83.0 \mathrm{~cm}$; W= $0.15-5.7 \mathrm{Kg}$ ) was analyzed. More than 50 species of phytoplankton and zooplankton were recorded in the intestines of the Catfishes, beside other benthic and pelagic organisms and high plant debris. Nevertheless the major food component (recorded in $>80 \%$ of analyzed fishes) was preyed Kinneret fishes of which Bleaks and Tilapias were the most common. Consequently, improvement of stocked fingerlings survival is recommended by removal or elimination of Catfishes from the vicinity of the stocking site. There is no evidence for enhancement of Catfish predation during the crisis period. The predatory impact of Catfish on other fish species in Lake Kinneret did not change but should be considered as one of the parameters for fishery improvement design.

\subsubsection{Periodical Fluctuations and the El-Niño/Southern Oscillation (ENSO) Effect}

Figures 8-12 present the background of the S. galilaeus temporary decline: Bleak fishery dropped down since early 1990's (Figure 8); the landings of S. galilaeus sharply declined during the 2000's (Figure 9). The seasonality of several factors represent complete or partial time overlap during the crisis time frame 1990-2010. The periodical overlap of landing decline (1990), reduced stocking (2000) (Figure 10), Bleaks proliferation (Figure 12) and limnological changes (from 1994) confirm respective responses of $S$. galilaeus lake stock.

Two ANOVA Tests $(\mathrm{p}<0.05)$ for the evaluation of the fluctuation of the S. galilaeus landings were done: 1) Annual catches during the entire period was divided into 5 seasonal groups: $1=1959-1969 ; 2=1970-1979 ; 3=$ 1980-1989; 4 = 1990-1999; and $5=2000-2010$; 2) For better indication of the catches decline during 1980-2010 the periodical split was done by 2 groups: $1=1980-1994$; and $2=1995-2010$. Results are given in Table 1 and Table 2.

Results presented in Table 1 indicate higher landings during 1980-1999. During most of this period the Kinneret ecosystem structure was optimal for S. galilaeus and lower landings earlier are probably due to regulations and availabilities of other species (especially Bleaks) but later (after the 1990's) the decline was influenced by ecological and management conditions.

Results in Table 2 comparatively evaluates the decline period split between early (1980-1994) and late (19952010) seasons.

Results in Table 2 indicates lower landings during the $2^{\text {nd }}$ period when ecological and management changes were existed. It is suggested that the natural and anthropogenic maintenance parameters for S. galilaeus in Lake Kinneret were deteriorated during late 1990's and the 2000's. Evaluation of periodical fluctuations of the annual catches of S. galilaeus as "smoothed" by LOWESS (0.8) (Figure 9) indicates an increase of landings from 1960 to1994 and decline later. We therefore suggest that the decline was a result of changes of the Kinneret ecosystem structure and the 2007-2008 crisis is not a disposable case but part of a long term process: quasi-cyclic fluctuations were documented by Pizanti et al. [13] and Pizanti [14]. Pizanti [14] indicated a decline of landing of S. galilaeus during the 2000's but predicted a close future recovery. Pizanti et al. [13] indicated an eleven

Table 1. ANOVA test $(\mathrm{p}<0.05)$ comparative evaluation of 5 groups: seasonal averages (SD) and significance level (p) of annual catches (AC) of S. galilaeus (SG) and significance (p) levels are given.

\begin{tabular}{cccc}
\hline Periodical Group & Average AC & SD & Significance Level $(\mathrm{p})$ \\
\hline A $=1959-1969$ & 177 & 28 & A $<$ C $(0.0021)$; C $<$ D $(0.0066)$ \\
B = 1970-1979 & 168 & 25 & A $<$ D $(<0.0001) ;$ C $>$ E $(<0.0001)$ \\
C = 1980-1989 & 285 & 76 & B $<$ C $(0.0014)$ \\
D = 1990-1999 & 383 & 112 & B $<$ D $(<0.0001)$ \\
E = 2000-2010 & 126 & 104 & D $>$ E $(<0.0001)$ \\
\hline
\end{tabular}

Table 2. ANOVA test $(\mathrm{p}<0.05)$ comparative evaluation of 2 groups: seasonal averages (SD) and significance level (p) of annual catches (AC) of S. galilaeus (SG) and significance (p) levels are given.

\begin{tabular}{cccc}
\hline Periodical Group & Average AC & SD & Significance Level (p) \\
A $=1980-1994$ & 317 & 115 & A > B (0.0315) \\
B = 1995-2010 & 207 & 153 & \\
\hline
\end{tabular}




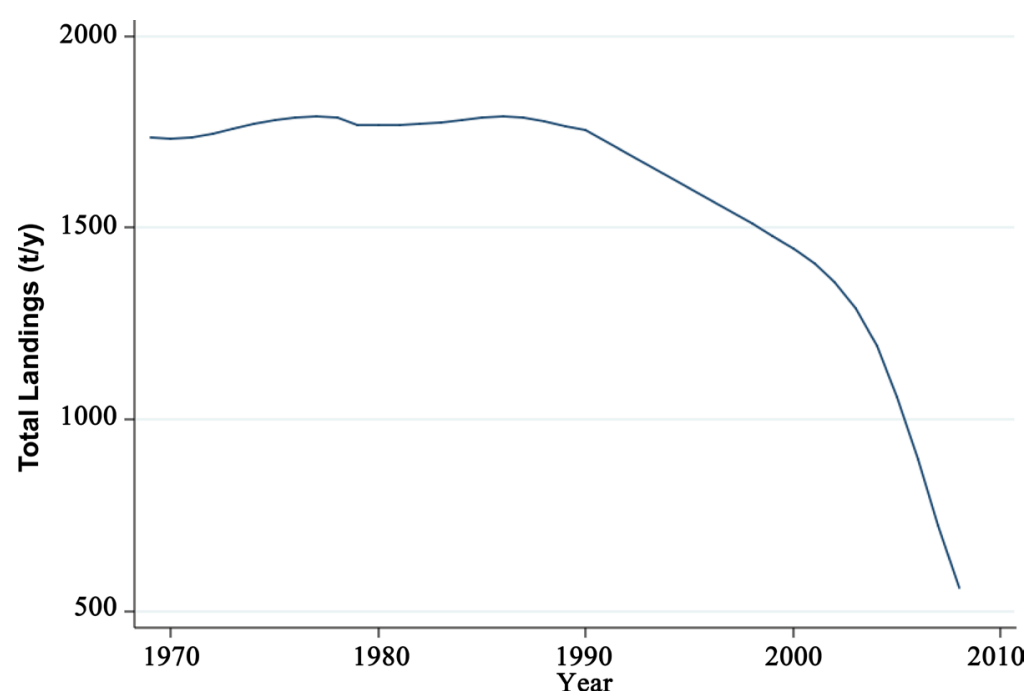

Figure 11. Kinneret fishery total landings (t/y) 1970-2000 LOWESS (0.8).

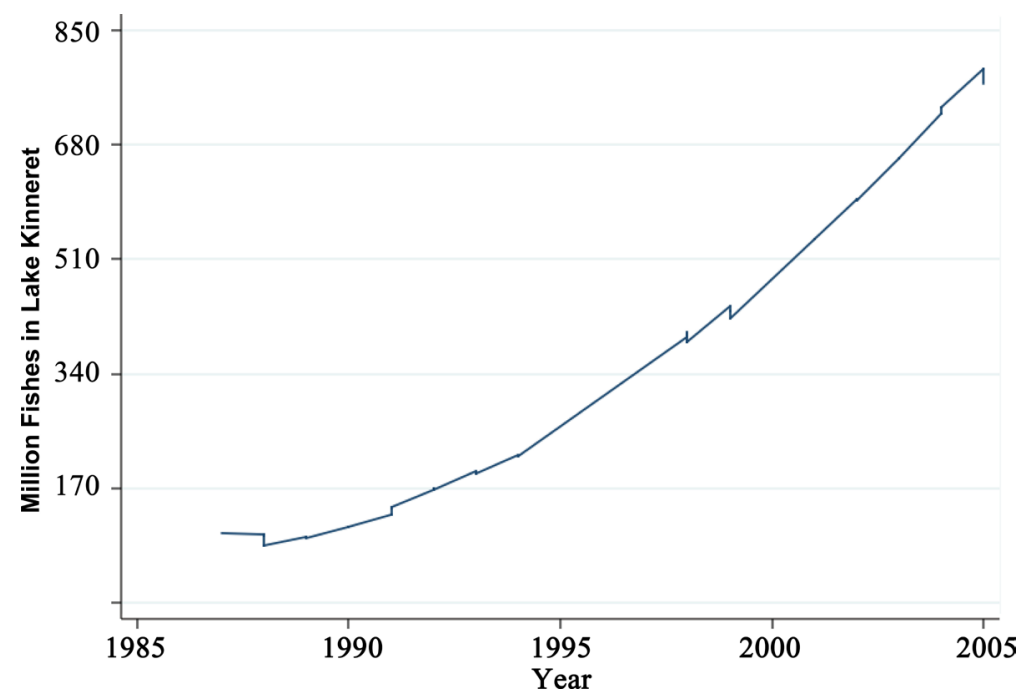

Figure 12. Total fish number in Lake Kinneret as reported by acoustic surveys (1987-2005).

years frequency of cyclical landings with ups and downs. They [13] analyzed a data set of annual (1935-2003) landings and concluded an 11 years cycles $\left(r^{2}=0.344\right.$; $\left.p<0.01\right)$ with amplitude of three times difference between the minimal and maximal consecutive cyclical values. The impacts of fishing net mesh size, Catch Per Unit effort (number of boats and day/night activity) and dimensions were eliminated and three consecutive annual catches were averaged and plotted as 3 years running averages curve.

The strong connection between El-Niño and the Southern Oscillation Index is recognized since 1970. Therefore, it was termed as El-Niño/South Oscillation (ENSO) case. This event starts with change in the Sea Surface Temperature (SST) in the Pacific Ocean and is affecting weather pattern at a great distance from the Pacific such as the Mediterranean region including Lake Kinneret and its drainage basin. The precise mechanism of the impact is not yet clearly known. Connections between SST in the Pacific Ocean (El Niño) and climate conditions in the Mediterranean region were found and documented [15]-[20]. It was indicated that Israel gets above average rainfall across the winter season during El Niño years, and is below average in La Niña years (Price et al. 1998; Alpert and Reisin 1986). The relationship is not linear, that is, a strong El-Niño does not always result in the rainiest season, while an average El Niño can cause heavy flooding in Israel. It was suggested that the reason for the connection is the equator-ward migration of the polar jet stream (and hence storm tracks) during El-Niño winters in the Mediterranean zone [16]-[18]. The two cases of El-Niño and El-Niña are creating contradictory 
climate trend of changes. El-Niño creates higher precipitation regime, higher wind velocities, and colder temperatures. After 1976 there is a significant trend of higher frequencies, durations and intensities of El-Niño relative to El-Niña. The cyclic pattern of ENSO events represents cycle frequencies of 2 - 7 years. Exceptional intensities of ENSO case were recorded in 1982-83, 1997-98, 2009-10 and presently predicted for 2015-16. Data record of the Pacific SST and respectively El-Niño development indicates several years with exceptional low temperatures and high precipitation in Israel with consequent high rate of Kinneret water level [16].

\subsubsection{Fish Net Mesh-Size}

During the second half of the 1990's an incorrect instruction was implemented: reduction of fishing net mesh size from 80 to $72 \mathrm{~mm}$. This instruction caused size of marketed S. galilaeus to become smaller and probably suppressing recruitment below the optimal level needed for the maintenance of long term sustainability. Moreover, the proliferation of the small body size, the unwanted and not fished, the Bleaks, was documented by long term (1987-2005) echo-surveys (Figure 12). Bleaks can be harvested only by small mesh size nets if market demands are available.

\subsubsection{S. galilaeus Introduction}

The reduction of stocking during the 2000's is clearly shown in Figure 10. Comparative ANOVA Test $(\mathrm{p}<0.05)$ between two periods of stocking prominently confirms this decline. The stocking record (annual numbers of stocked fingerlings), 1984-2010 was divided into two periodical groups: Group $1=1984-2002$, and Group $2=$ 2003-2010. The results are given in Table 3.

\section{Cormorant}

\subsection{European Case}

The Great Cormorant (Phalacrocorax carbo) is a worldwide well-known migratory bird. The migratory Cormorants stay annually in Israel from November to March coming from Europe where they breed during Spring-Summer. Cormorant feed on fish throughout the year. Cormorant catch their fish prey by diving, commonly to depths between 5 and $15 \mathrm{~m}$ in Lake Kinneret (personal observation, unpublished data). Their diving lasts normally 20 - 30 seconds and they bring the prey to surface. Fisher and fishery managers consider cormorants as their competitor. The conflict between cormorants on one hand and fisheries and lake management on the other is focused at reasonable landings and ecological protection. The Cormorant damage to fishery and lake management are drastic not only in Europe but in other parts of the world as well (Takahashi, et al. 2006; Natsumeda et al. 2010). The cormorant population in Europe and consequently migration to Israel, has significantly increased during the last 25 years, mostly due to the implementation of endangered birds protection policy adapted by the EEC [21].

Conclusions presented in a report of a European workshop that was organized by FAO-EIFAC in Brussel [21] emphasized the need for long-term sustainability proposal of aquatic ecosystems and aquaculture under the threat of predation damage caused to fish by cormorants. The conference background was the increase of cormorant population up to 1.8 million birds accompanied by severe damages to aquaculture, fish population in lakes and irreversible negative changes of vegetation. One of the recommendations documented in the final report is shooting about 43,000 birds annually.

\subsection{The History of Cormorants in Israel}

The Great Cormorant (Phalacrocorax carbo) is a component of the native Avifauna of Israel. The old shallow

Table 3. Comparative ANOVA test $(\mathrm{p}<0.05)$ of $S$. galilaeus $\left(10^{6}\right.$ fingerlings $\left.>8 \mathrm{~g} / \mathrm{ind}\right)$ stocking in Lake Kinneret between two periods: group 1 = 1984-2002; group 2 = 2003-2010. Group averages (SD) and probability (p) for significant (S) difference are given.

\begin{tabular}{cccc}
\hline Group & Average $10^{6}$ Stocked & SD & A (Probability) \\
A & 4.0 & 1.5 & B \\
$1984-2002$ & & & 0.0045 \\
B & 2.2 & 1.1 & \\
$2003-2010$ & & & \\
\hline
\end{tabular}


lake Hula located northern to Kinneret was densely populated by Cormorants. Fish aquaculture development in the Hula Valley attracted Cormorants to the region and fish predation was enhanced thoroughly. During 19501990 the Cormorants caused severe damage to aquaculture and to the fish populations in Lake Kinneret. However, a successful deportation of them in northern Israel enhanced inland migration to other parts of the country. Active deportation of Cormorants by the farmers was carried out again, than the birds found a refuge in Lake Kinneret. Presently, about 7500 Cormorants stay in the lake Kinneret and in the vicinity during late September-Early March (170 days).

\subsection{Cormorants Damage to the Lake Kinneret Ecosystem}

The feeding habits of cormorants indicate a daily ration varying between 300 and $1000 \mathrm{~g} / \mathrm{bird} / \mathrm{day}$ and the most common values are 500 and 700 g/bird/day [22] [23]. Analysis of the birds diet [24] revealed that during late September-November the prey is mostly comprised of Bleaks and other small Tilapias, and later, young subcommercial sized S. galilaeus (35 - 50 g/ind) become the dominant component. We consider the Cormorant daily ration as 500 grams and number of birds-7000. Therefore the entire preyed fish biomass is the following: 7000 birds $\times 0.5 \mathrm{~kg} \times 170$ days = app. 400 tons of which 235 tons are probably S. galilaeus. The birds occupy during nights several sites covered by tall trees and bushes as resting stations and they are assembled in big flocks throughout early morning and noon time daily from all sites to prey fish in the lake. It has to be considered that the preyed $S$. galilaeus size ( $<100$ g per fish) are below commercially permitted size that is to say that the potential damage is at least twice as high (legal fishing size $>200 \mathrm{~g} / \mathrm{fish}$ ). Fish specimen weighted $100 \mathrm{~g}$, if not preyed might grow up to $200 \mathrm{~g}$ which can be legally marketed. Consequently, the commercial value of such losses is between 1.5 and 3.0 million US\$. Such a damage to Fisher's [25] income and ecologically to the system can be reduced by deportation of the cormorants. As the fishing pressure of Cormorant community is ecologically located on top of the tropho-pyramid, and high fishing pressure already exist by the commercial fisheries, S. galilaeus is fleeing to deeper depths as a refuge from Cormorant and fisher cannot find them. As the deeper feeding depths of S. galilaeus in the lake is inhabited by S. galilaeus fishing operation become more complicated and some of the fishing gear become irrelevant. The decline of the fishing yield in this case, is Inevitable. In this case, the decline of the catch does not necessarily the result of population decline in the lake but the opposite, and not fished. The recognition of continual changed dynamics of the target fish behavior as crucial for effective fishing and sustainable management of the ecosystem is ultimately required.

\section{Outbreak of Lethal Virus to Tilapia [26]}

In 1995 Fisher and technicians of the Fishery department reported to the Kinneret Committee of Fishery Management about damaged (destroyed) 1 or 2 eyes in specimen of S. galilaeus. Fish breeders also documented similar damages to Tilapias in aquaculture pond in the drainage basin of Lake Kinneret. In 2010 the level of infected S. galilaeus was approximated 3\% - 8\% of the total landings docked by purse-seiners. The collaboration between Purse-seiners Fisher and the fishery department team initiated a contact with an expert virologist in the Veterinary Institute, Department of Poultry and Fish Disease, The Kimron Veterinary Institute Bet Dagan, Israel, and the outbreak was intensively investigated. From early 2000's, mortality of S. galilaeus and Tristramella simonies simonis was recorded in Lake Kinneret. The etiological agent of the disease factor was described and his characteristics were documented [26]. Etiologically the virus is a novel RNA virus which externally destroy the fish eye (therefore its local title is "the virus of blindness") on one side and later the second eye. The virus (denomination: Tilapia Lake Virus: TiLV) was isolated and detection was revealed [26]. The TiLV was propagated in primary Tilapia's brain cells and induced a cytopathic effect within 5 - 10 days post infection. Tilapias injected intra-peritoneally by TiLV represented symptoms resembling the natural damages of kidneys, brain, skin and eye lenses with $>80 \%$ mortality. Cohabitation of healthy and infected fishes indicated contagious cases and $80 \%$ - 100\% mortality within a few days. Occasionally, other species (Tor canis, Tilapia zillii, Oreochromis aureus and Tristramella simonis simonis) were documented with damaged eyes.

\section{The Impact of El-Niño/Southern Oscillation (ENSO)}

It is suggested that the oscillated pattern of decline of $S$. galilaeus and enhancement of Bleaks population is connected with the events of ENSO. The enigmatic relation between ENSO events and fish population in Lake 
Kinneret is of a great curiosity. The zoogeographical origins of the Lake Kinneret fishes are Palaearctic (northern to Kinneret) and Ethiopian (southern to Kinneret). The Bleaks are Palaearctic and S. galilaeus as other cichlids-Ethiopian originated. The reproduction process is therefore different: Bleaks reproduce in winter and reproduction efficiency followed by enhanced population increment is better succeeded when precipitations are heavy during longer winter time (November to April) accompanied by low temperatures and consequently by high rate of water level (WL) increase. The strong relation between Bleaks larvae survivorship and high rate of WL elevation ( $>2 \mathrm{~cm}$ per day) was documented [5] .The optimal temperatures in late winter-spring time (AprilJuly) for the reproduction of $S$. galilaeus are contradictory higher: Reproduction activity begin when daily minimum of shallow waters $(<50 \mathrm{~cm})$ is above $21^{\circ} \mathrm{C}$ [5]. S. galilaeus maintain $3-4$ cycles of reproduction and therefore under ENSO conditions of longer winter duration of low temperatures in the shallows, number of reproduction cycles probably decline and population increment as well. A representative example is taken from [15] and compared with Kinneret fishery record: Lowest landings of S. galilaeus ever recorded in Lake Kinneret in 2007-2008 were corresponded to SST in the Pacific lower (ENSO case) than continuous running average record measured during 2007-2008.

Respective conclusions are the two contradictory development while ELNO conditions are existed: 1) heavy precipitations enhance WL increase and Bleaks are proliferated which is not good for both, fishery management and water quality protection; 2) the cold and longer winter condition is causing delay of the reproduction activity of $S$. galilaeus and consequently make the duration of reproductive season shorter with potentially decline of population increment which is not good for fishery management and for water quality protection, i.e. S. galilaeus fishery crisis. Other factors such as illegal fishing net meshes, Cormorant predation, lowering of stocking and of course Bleaks food competition accelerated the natural cyclic decline and our prediction of recovery is acceptable [13] [14]. We therefore suggest that a principle factor affecting reproduction efficiency of S. galilaeus is not food availability and not submerged plant refuge but availability of optimal temperatures. Unfortunately we do not have a long term record of temperatures in the Kinneret shallows $(<50 \mathrm{~cm})$ due to technical difficulties. The inquiry about fishery crisis prior to the 2000's is legitimate. The answer is given in the regime (amplitude) of the up-down fluctuations: they were smaller before the 2000's and greater afterward. The fluctuating cyclic trend was documented in [13] [14] but concluded by prediction of population decline recovery. Data in Tables 1-3, prominently represent the trend of landing decline during the 2000's. Date given in [15] evidently proof higher frequency and intensity of ENSO events during the 2000's. Moreover, it is suggested that the "downs" level was confounded by higher capacities of fingerling stocking and the presence of smaller number of Cormorant resulted in reduction of predation pressure. During the 2000's Cormorant piscivory was enhanced, stocking was reduced and Bleaks population explosion occur. The sharp decline of S. galilaeus landings during 2006-2009 reflected the situation of all-inclusive conditions.

\section{Summary}

During the 2000's there was a significant decline in commercial Lake Kinneret fish landing. Several factors are suggested to be the reasons for that: limnological changes in the Kinneret ecosystem structure which enhanced food resource competition between S. galilaeus and Bleaks; the proliferation of Bleaks population in the lake resulted by their fishing stop which is due to no market demands; intensification of predation of sub-commercial sized adult S. galilaeus by Cormorants (Phalacrocorax carbo) and stocked fingerlings by Catfish (Clarias gariepinus); reduction of $S$. galilaeus stocking; the usage of smaller mesh-size fishing nets; the outbreak of the virus of blindness (TiLV-RNA virus). Higher frequencies and intensities of ENSO also contributed to the decline of S. galilaeus landings. Epilog: after the recorded minimal landing in 2008, a recovery was documented (Figure 13). The decline of the lake stock and landings of S. galilaeus during 2007-2008 and the further recovery were integrated part of the natural fluctuations. Nevertheless, the decline range was an exceptional one. The factors which enhanced the decline are those which were described here: the increase of Bleak stock and strengthening of food sources competition, together with the replacement of Peridinium by Cyanobacteria; the intensification of Cormorant predation; the use of small meshes on fishing net; and the reduction of S. galilaeus introduction. The enhanced rate of decline as part of natural process trend was evidently supported by the further recovery. It can be therefore conclusively recommended to achieve the following anthropogenic interventions: Cormorant deportation; renewal of Bleaks fishery; enhancing stocking of S. galilaeus; renewal of the larger 


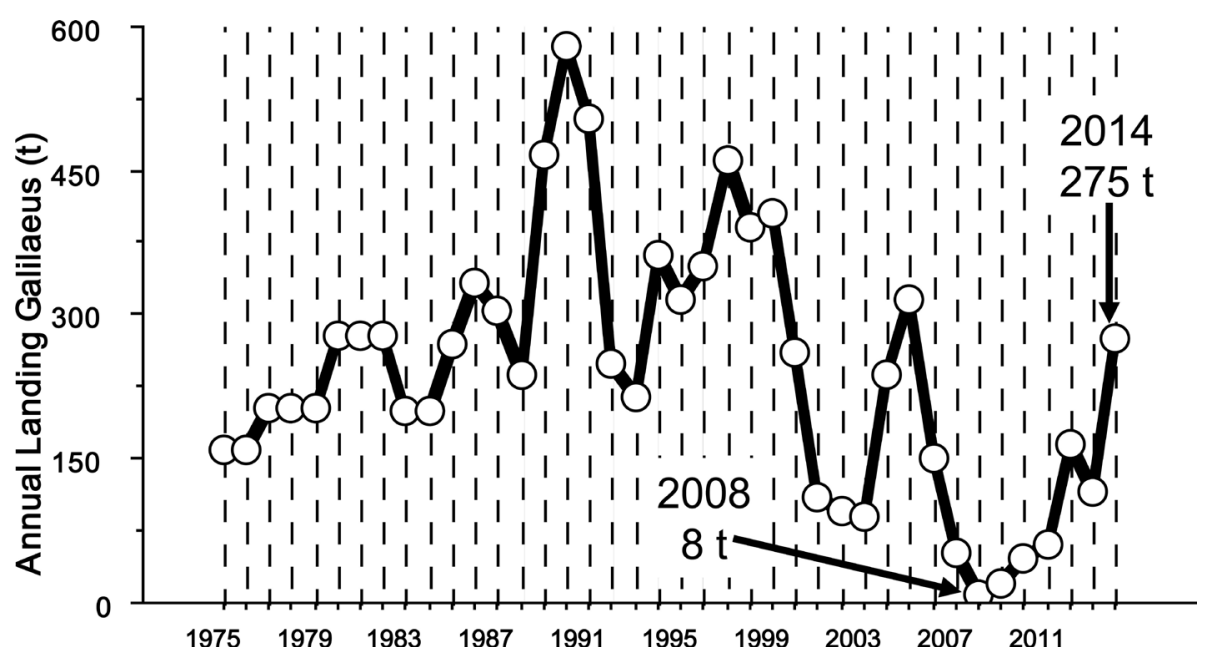

Figure 13. Sarotherodon galilaeus annual landings (t/y) during 1975-2014.

meshes of fishing nets legislation. It is a supportive concept free of contradictions.

\section{References}

[1] Gophen, M. (2015) The Impact of Available Nitrogen Deficiency on Long-Term Changes in the Lake Kinneret Ecosystem. Open Journal of Ecology, 5, 147-157. http://dx.doi.org/10.4236/oje.2015.54013

[2] Berman, T., Serruya, C., Gophen, M., Sukenik, A. and Zohary, T., Eds. (2013) KLL-IOLR Lake Kinneret Data Base (LKDB)-1970-2013, Annual Reports.

[3] Fishery Department Agriculture Ministry-Lake Kinneret Branch (1970-2013) Fisheries in Israel: Chapters: Lake Kinneret.

[4] Gophen, M., Smith, V.H., Nishri, A. and Threlkeld, S.T. (1999) Nitrogen Deficiency, Phosphorus Sufficiency, and the Invasion of Lake Kinneret, Israel, by $\mathrm{N}_{2}$-Fixing Cyanobacterium Aphanizomenon ovalisporum. Aquatic Sciences, 1, 1-14. http://dx.doi.org/10.1007/pl00001326

[5] Gophen, M. (2004) Ecohydrological Management of Lake Kinneret: A Case Study. Ecohydrology and Hydrobiology, 4, 397-408.

[6] Gophen, M. (2004) Hydrology and Management of Lake Kinneret Aimed at Water Quality Protection. In: Zreiny, F. and Jaeschke, W., Eds., Water in the Middle East and in North Africa: Resources, Protection, and Management, SpringerVerlag, Berlin, 207-226. http://dx.doi.org/10.1007/978-3-662-10866-6_18

[7] Gophen, M. (2008) Long Term (1970-2001) Eco-Hydrological Processes in Lake Kinneret and Its Watershed. In: Zereini, H., Ed., Climatic Changes and Water Resources in the Middle East and in North Africa, Springer, Berlin, 373-402. http://dx.doi.org/10.1007/978-3-540-85047-2 24

[8] Gophen, M. (2011) The Cladoceran Trophic Status in the Nitrogen Limited Ecosystem of Lake Kinneret (Israel). Journal of Environmental Biology, 32, 455-462.

[9] Hessen, D.O. (2005) Aquatic Food Webs: Stoichiometric Regulation of Flux and Fate of Carbon. Peter Kilham Memorial Lecture. Verhandlungen des Internationalen Verein Limnologie, 29, 39-49.

[10] Urabe, J., Nakanishi, M. and Kawabata, K. (1995) Contribution of Metazoan Plankton to the Cycling of Nitrogen and Phosphorus in Lake Biwa. Limnology and Oceanography, 40, 232-241. http://dx.doi.org/10.4319/lo.1995.40.2.0232

[11] Walline, P. (2005) KLL-Kinneret Limnlogical Laboratory-IOLR 1987-2005. Annual Reports.

[12] Spataru, P., Viveen, W.J.R. and Gophen, M. (1987) Food Composition of Clarias gariepinus (= C. lazera) (Cypriniformes, Clariidae) in Lake Kinneret (Israel). Hydrobiologia, 144, 77-82. http://dx.doi.org/10.1007/BF00008053

[13] Pisanti, S., Ben-Yami, M. and Talpaz, H. (1987) Quasi-Fluctuation in St. Peter’s Fish in Lake Kinneret and the Management Implications. A: The Cyclic and the Effect of Effort. Fisheries and Fish Breeding in Israel, 20, 26-38. (In Hebrew, English Abstract)

[14] Pisanti, S. (2005) Quasi-Cyclic Fluctuations in St. Peter's Fish Landings in Lake Kinneret-Continues. Fisheries and Fish Breeding in Israel, 1, 777-781. (In Hebrew, English Abstract)

[15] CPC.NOAA.gov. (2015) Climate Prediction Center-Monitoring and Data: ENSO-Previous Events. El-Niño/Southern 
Oscillation (ENSO), Historical El-Niño/La-Niña.

[16] Coline, P., Stone, L., Huppert, A., Rajagopalan, B. and Alpert, P. (1998) A Possible Link between EL-NIÑO and Precipitation in Israel. Geophysical Research Letters, 25, 3963-3966.

[17] Alpert, P. and Reisin, T. (1986) An Early Winter Polar Air Mass Penetration to the Eastern Mediterranean. Monthly Weather Review, 114, 1411-1418. http://dx.doi.org/10.1175/1520-0493(1986)114<1411:AEWPAM>2.0.CO;2

[18] Rajagopalan, B.U. and Cane, M.A. (1997) Anomalous ENSO Occurrence: An Alternate View. Journal of Climate, 10, 235-2357. http://dx.doi.org/10.1175/1520-0442(1997)010<2351:AEOAAV >2.0.CO;2

[19] Wuethrich, B. (1995) El-Niño Goes Critical. New Scientist, 4, 32-35.

[20] Trenberth, K.E. and Hoar, T.J. (1997) El Niño and Climate Change. Geophysical Research Letters, 24, $3057-3060$. http://dx.doi.org/10.1029/97GL03092

[21] FAO EIFAC Final Report (2008) Occasional Paper No. 41. FAO, Rome, 34 p.

[22] Gremillet, D., Schmid, D. and Culik, B. (1995) Energy Requirements of Breeding Great Cormorants Phalacrocorax carbo sinensis. Marine Ecology Progress Series, 121, 1-9. http://dx.doi.org/10.3354/meps121001

[23] Hatch, J., Brown, K., Hogan, G. and Morris, R. (2000) Great Cormorant (Phalacrocorax carbo). The Birds of North America Online, 553, 1-20. http://bna.birds.cornell.edu.proxy.lib.umich.edu/bna/species/553

[24] Artzi, I. and Gissin, G. (2012) Food Composition of Cormorant in Lake Kinneret. Interim Report, NPA, 46p. (In Hebrew)

[25] Johnson, J. and McCullough, R.D. (2007) Diet Composition and Fish Consumption of Double Crested Cormorants from the Pigeon and Snake Island Colonies of Eastern Lake Ontario in 2007. Lake Ontario Annual Report 2007. Section, 16, 1-9.

[26] Eyngor, M., Zamostiano, R., Krmbou, J.E., Berkovitz, T.A., Borcovier, H., Tinman, S., Lev, M., Hurvitz, A., Galeotti, M., Bachrach, E. and Eldar, A. (2014) Identification of Novel RNA Virus Lethal to Tilapia. Journal of Clinical Microbiology, 52, 4137-4146. http://dx.doi.org/10.1128/JCM.00827-14 